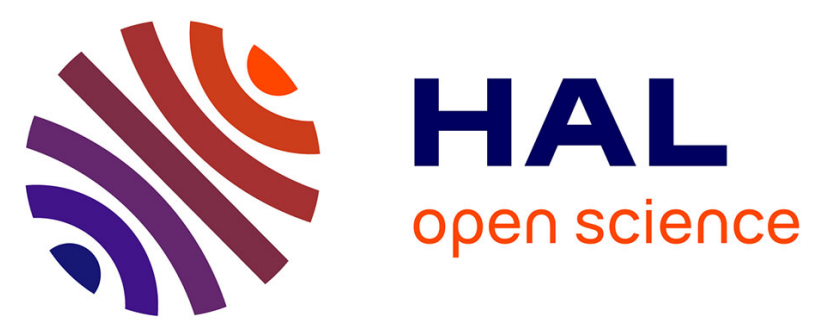

\title{
Localization, Characterization, and Second Messenger Coupling of Pituitary Adenylate Cyclase-Activating Polypeptide Receptors in the Fetal Human Adrenal Gland during the Second Trimester of Gestation*
}

Laurent Yon, Lyne Breault, Vincent Contesse, Grégory Bellancourt, Catherine Delarue, Alain Fournier, Jean-Guy Lehoux, Hubert Vaudry, Nicole Gallo-Payet

\section{- To cite this version:}

Laurent Yon, Lyne Breault, Vincent Contesse, Grégory Bellancourt, Catherine Delarue, et al.. Localization, Characterization, and Second Messenger Coupling of Pituitary Adenylate CyclaseActivating Polypeptide Receptors in the Fetal Human Adrenal Gland during the Second Trimester of Gestation*. Journal of Clinical Endocrinology and Metabolism, 1998, 83 (4), pp.1299-1305. 10.1210/jcem.83.4.4690 . hal-02334689

\section{HAL Id: hal-02334689}

https://hal-normandie-univ.archives-ouvertes.fr/hal-02334689

Submitted on 29 Oct 2019

HAL is a multi-disciplinary open access archive for the deposit and dissemination of scientific research documents, whether they are published or not. The documents may come from teaching and research institutions in France or abroad, or from public or private research centers.
L'archive ouverte pluridisciplinaire HAL, est destinée au dépôt et à la diffusion de documents scientifiques de niveau recherche, publiés ou non, émanant des établissements d'enseignement et de recherche français ou étrangers, des laboratoires publics ou privés. 


\title{
Localization, Characterization, and Second Messenger Coupling of Pituitary Adenylate Cyclase-Activating Polypeptide Receptors in the Fetal Human Adrenal Gland during the Second Trimester of Gestation*
}

\author{
LAURENT YON, LYNE BREAULT $\dagger$, VINCENT CONTESSE, \\ GRÉGORY BELLANCOURT $\$$, CATHERINE DELARUE, ALAIN FOURNIER, \\ JEAN-GUY LEHOUX, HUBERT VAUDRY§, AND NICOLE GALLO-PAYET
}

\author{
European Institute for Peptide Research (IFRMP 23), Laboratory of Cellular and Molecular \\ Neuroendocrinology, Institut National de la Santé et de la Recherche Médicale U413, UA CNRS, \\ University of Rouen (L.Y., V.C., G.B., C.D., H.V.), 76821 Mont-Saint-Aignan, France; Service of \\ Endocrinology (L.B., N.G.-P.), Department of Medicine, Department of Biochemistry (J.-G.L.), Faculty \\ of Medicine, University of Sherbrooke, Sherbrooke, Quebec, Canada J1H 5N4; and INRS Santé, \\ University of Quebec (A.F.), Pointe-Claire, Quebec, Canada H9R $1 G 6$
}

\begin{abstract}
The distribution and pharmacological properties of pituitary adenylate cyclase-activating polypeptide (PACAP) receptors were studied in the fetal human adrenal gland during the second trimester of gestation. Autoradiographic studies, using $\left[{ }^{125} \mathrm{I}\right] \mathrm{PACAP} 27$ as a radioligand, revealed that PACAP-binding sites are exclusively located on chromaffin cells of adrenals from fetuses 14-20 weeks old. Biochemical characterization of binding revealed the occurrence of a single class of PACAP-binding sites with a dissociation constant value of $0.32-0.74 \mathrm{nmol} / \mathrm{L}$ and a binding capacity of $0.30-0.81 \mathrm{pmol} / \mathrm{mg}$ wet tissue. PACAP27 and PACAP38 were equipotent in competing for $\left[{ }^{125} \mathrm{I}\right] \mathrm{PACAP} 27$ binding $\left(\mathrm{IC}_{50}=0.28-0.64 \mathrm{nmol} / \mathrm{L}\right.$ and $0.15-0.81$ $\mathrm{nmol} / \mathrm{L}$, respectively), and the Hill coefficients were close to 1 . In
\end{abstract}

contrast, vasoactive intestinal polypeptide was much less efficient in displacing the tracer $\left(\mathrm{IC}_{50}=4-362 \mathrm{nmol} / \mathrm{L}\right)$, and the Hill coefficients were less than 0.6. PACAP38 induced a dose-dependent increase in cAMP production in fetal human adrenal cell suspension $\left(\mathrm{ED}_{50}=\right.$ $0.07 \pm 0.02 \mathrm{nmol} / \mathrm{L}$ ), as well as in cells maintained in culture for 5 days $(5.4 \pm 1.8 \mathrm{nmol} / \mathrm{L})$. In constrast, PACAP38 induced a modest increase in inositol phosphate formation. These data indicate that type I PACAP receptors are present in the early stages of the human medulla organization during the process of migration of chromaffin cells from the periphery to the central part of the gland. The present results suggest that PACAP could be involved in the regulation of the human adrenochromaffin cells during ontogenesis. (J Clin Endocrinol Metab 83: $1299-1305,1998)$
$\mathrm{P}$ TUITARY adenylate cyclase-activating polypeptide (PACAP) is a 38 -amino acid $\alpha$-amidated neuropeptide initially isolated from the ovine hypothalamus because of its ability to stimulate adenylyl cyclase activity in rat anterior pituitary cells (1). PACAP38 possesses an internal cleavageamidation consensus sequence $\left(\mathrm{Gly}^{28}-\mathrm{Lys}^{29}-\mathrm{Arg}^{30}\right)$ and can

Received September 9, 1997. Revision received December 22, 1997 Accepted December 31, 1997.

Address all correspondence and requests for reprints to: Dr. Hubert Vaudry, European Institute for Peptide Research (IFRMP 23), Laboratory of Cellular and Molecular Neuroendocrinology, Institut National de la Santé et de la Recherche Médicale U413, UA CNRS, University of Rouen, 76821 Mont-Saint-Aignan, France. E-mail: hubert.vaudry@ univ-rouen.fr.

* This work was supported by the Medical Research Council of Canada (MRC MT13679, to N.G.-P. and J.-G.L.), the Institut National de la Santé et de la Recherche Médicale (INSERM U413), a France-Québec exchange programme (Coopération Scientifique et Technologique Franco-Québécoise (PVP-73-9, to N.G.-P. and H.V.), and the Conseil Régional de Haute-Normandie.

† Recipient of studentship from the Fonds de la Recherche en Santé du Québec et Fonds pour la Formation de Chercheurs et l'Aide à la Recherche.

$\ddagger$ Recipient of a studentship from the Conseil Régional de Haute-Normandie.

$\S$ Affiliated Professor at the Institut National de la Recherche Scientifique-Santé, Montréal. thus generate a 27 -residue $\alpha$-amidated peptide (PACAP27) that exhibits the same biological activity as PACAP38 $(2,3)$. The $\mathrm{NH}_{2}$-terminal region of PACAP shows $68 \%$ sequence similarity with vasoactive intestinal polypeptide (VIP), identifying PACAP as a member of the VIP/secretin/glucagon superfamily. The primary structure of PACAP has been remarkably conserved during evolution (4), indicating that the peptide plays important biological functions.

Two types of PACAP-binding sites have been characterized so far (see Ref. 5 for review). Type I binding sites have a high affinity (dissociation constant $\left(\mathrm{K}_{\mathrm{d}}\right) \sim 0.2$ $\mathrm{nmol} / \mathrm{L})$ for PACAP38 and PACAP27 and a much lower affinity $\left(\mathrm{K}_{\mathrm{d}} \sim 1 \mu \mathrm{mol} / \mathrm{L}\right)$ for $\operatorname{VIP}(5,6)$, whereas type II binding sites have similar affinity for PACAP38, PACAP27, and VIP (7). Both receptor subtypes belong to the seven-transmembrane domain $\mathrm{G}$ protein-coupled receptor superfamily $(8-10)$ and are differentially coupled to adenylyl cyclase and phospholipase C (10). PACAP and PACAP-binding sites are widely distributed in the central nervous system and in peripheral organs $(7,11)$. In particular, the occurrence of PACAP and its recognition sites has been demonstrated in various endocrine glands, including the pituitary, pancreas, testis, ovary, and adrenal $(3,5,7,12,13)$. 
Developmental studies have shown that, in the brain, the expression of PACAP and PACAP-binding sites undergoes important variations during ontogenesis. For instance, a high concentration of PACAP has been detected in the rat cerebellum between postnatal days 4 and $20(14,15)$. Similarly, intense expression of PACAP receptors has been observed in the proliferative zone of the cerebellar cortex during the postnatal period $(16,17)$, suggesting that PACAP exerts neurotrophic activities during development. In support of this hypothesis, it has been shown that PACAP promotes cell survival and neurite outgrowth in cultured cerebellar granule cells (18) and stimulates proliferation of folliculo-stellate cells (19).

The occurrence of PACAP and PACAP receptors in the adult adrenal gland $(13,20-22)$ and the observation that PACAP modulates proliferation and differentiation of adrenal chromaffin cells (23-25) suggest that PACAP may play a role in the ontogeny of the adrenal gland. The fetal human adrenal gland is composed of morphologically and functionally distinct steroid-secreting tissues: a thin neocortex that produces cortisol and a large fetal zone that produces massive amounts of dehydroepiandrosterone sulfate $(26,27)$. During fetal life, cells derived from the ectoderm migrate inside the gland to form the medulla $(28,29)$. After birth, the fetal zone involutes, and the cortex develops and differentiates into the three characteristic zones present in the adult adrenal gland. These profound changes in the organization of the gland suggest that trophic factors, such as PACAP, may control the modeling of the tissue during ontogenesis. However, the distribution and function of PACAP receptors have not yet been studied in the adrenal during development.

In the present study, we have localized PACAP-binding sites in the fetal human adrenal gland by autoradiography, and we have investigated the effect of PACAP on secondmessenger systems in suspended and cultured fetal adrenal cells.

\section{Materials and Methods}

\section{Reagents and peptides}

Myo- $\left[{ }^{3} \mathrm{H}\right]$ inositol $(10-20 \mathrm{Ci} / \mathrm{mmol})$ and $\left[{ }^{3} \mathrm{H}\right]$ adenine $(24 \mathrm{Ci} / \mathrm{mmol})$ were purchased from Amersham (Oakville, Ontario, Canada). $\mathrm{Na}^{125} \mathrm{I}$ (2000 Ci/mmol) was obtained from Amersham (Les Ulis, France). ATP, cAMP, and deoxyribonuclease were supplied by Sigma (St. Louis, MO). Eagle's MEM, collagenase, and Opti-MEM medium were obtained from Gibco (Burlington, Ontario, Canada). PACAP27 was from Bachem (Marina Delphen, CA). BSA was from Boehringer (Mannheim, Germany). PACAP38 and VIP were synthesized by the solid-phase methodology previously described (30).

Monoiodinated PACAP27 was used as a tracer. Iodination of synthetic PACAP27 was performed by means of the lactoperoxidase technique, and the radioligand was purified by reverse-phase high-performance liquid chromatography, as previously described $(31,32)$. The specific radioactivity of the radioligand was approximately 800 $\mathrm{Ci} / \mathrm{mmol}$.

\section{Tissue preparation}

Fetal human adrenal glands were obtained from fetuses between 14 and 20 weeks old (post conception) at the time of therapeutic abortion. Fetal ages were estimated by foot length and time after the last menstruation, according to Streeter (33). After removal, glands were kept on ice in McCoy's medium and transported within $4 \mathrm{~h}$ to the laboratory. The project was approved by the human subject review committees at our institutions. Immediately after collection, glands were cleansed of fat and were either frozen at $-80 \mathrm{C}$ or processed for cell dispersion.

\section{Autoradiographic studies}

Frozen adrenal glands were sliced into $10-\mu \mathrm{m}$ sections on a cryostat (Frigocut, Reicher-Jung, Germany). Sections were thaw-mounted on gelatin-coated slides, placed in a desiccator overnight at $4 \mathrm{C}$, and processed for autoradiography, as previously described (16). Tissue slices were preincubated for $30 \mathrm{~min}$ at $24 \mathrm{C}$ in $50 \mathrm{mmol} / \mathrm{L}$ Tris buffer (pH 7.4) containing $1 \% \mathrm{BSA}, 5 \mathrm{mmol} / \mathrm{L} \mathrm{MgCl}_{2}, 32 \mathrm{mmol} / \mathrm{L}$ sucrose, and 0.5 $\mu \mathrm{g} / \mathrm{mL}$ bacitracin. The sections were incubated with $\left.{ }^{125} \mathrm{I}\right] \mathrm{PACAP} 27$ (50 $\mathrm{pmol} / \mathrm{L}$ ) for $2 \mathrm{~h}$ at $24 \mathrm{C}$ in the same buffer, supplemented with $2 \%$ BSA and $100 \mathrm{KIU} / \mathrm{mL}$ aprotinin (Hoechst Laboratories, Puteaux, France). Nonspecific binding was determined by adding $1 \mu \mathrm{mol} / \mathrm{L}$ PACAP27. For competition studies, the sections were incubated with $50 \mathrm{pmol} / \mathrm{L}$ tracer in the presence of various concentrations of unlabeled PACAP27, PACAP38 $\left(10^{-10}\right.$ to $\left.10^{-6} \mathrm{~mol} / \mathrm{L}\right)$ or VIP $\left(10^{-9}\right.$ to $\left.10^{-6} \mathrm{~mol} / \mathrm{L}\right)$. The slices were washed three times for 5 -min periods at $4 \mathrm{C}$ in $50 \mathrm{mmol} / \mathrm{L}$ Tris buffer containing $0.1 \% \mathrm{BSA}, 5 \mathrm{mmol} / \mathrm{L} \mathrm{MgCl}_{2}$, and $0.5 \mu \mathrm{g} / \mathrm{mL}$ bacitracin. Finally, the sections were dried under a cold-air stream and apposed onto Amersham Hyperfilm- ${ }^{3} \mathrm{H}$ for 10 days.

The gray levels of the autoradiograms were measured by means of a computer-assisted image analysis station BIO 500 (Biocom, Les Ulis, France), as previously described (34). The concentration of ligand which causes $50 \%$ inhibition of the binding values $\left(\mathrm{IC}_{50}\right)$ and Hill coefficients were determined using the Sigma Plot program (Jandel Scientific, Corte Madera, CA).

\section{Histochemical and immunological procedures}

After exposure for autoradiography, adrenal sections were fixed with vapors of paraformaldehyde $(24 \mathrm{~h}, 60 \mathrm{C})$. Tissue slices were either stained with hematoxylin-eosin or immunostained with antibodies against human chromogranin A (CgA; Dako, Glostrup, Denmark), a marker of chromaffin cells (29). Briefly, tissue sections were incubated overnight at $4 \mathrm{C}$ with the $\mathrm{CgA}$ antiserum, diluted 1:100 in phosphate buffer (PB; $0.1 \mathrm{~mol} / \mathrm{L}, \mathrm{pH} 7.4$ ) containing $0.3 \%$ Triton $\mathrm{X}-100$ and $1 \%$ BSA. After several rinses in $\mathrm{PB}$, the sections were incubated for $90 \mathrm{~min}$ at room temperature with fluorescein isothyocyanate-conjugated goat antirabbit $\gamma$-globulins (GAR/FITC; Caltag Laboratories, San Francisco, CA) diluted 1:100. Finally, the sections were rinsed in PB and mounted in PB/glycerol (1:1). The preparations were examined on a Leitz Orthoplan (Heidelberg, Germany) microscope equipped with a photographic system.

\section{Dissociation of adrenal cells}

The adrenal glands from 18- to 20-week-old fetuses were finely chopped into 1- to 2-mm pieces. The tissue fragments were subjected to enzymatic dissociation in Eagle's MEM containing collagenase ( $2 \mathrm{mg} /$ $\mathrm{mL})$ and deoxyribonuclease $(25 \mu \mathrm{g} / \mathrm{mL})$, as previously described (35). The tissue was mechanically dissociated by gentle aspiration, and dispersed cells were filtered and centrifuged for $10 \mathrm{~min}$ at $100 \times \mathrm{g}$. The cell pellet was resuspended in Opti-MEM containing $2 \%$ FBS, $100 \mathrm{U} / \mathrm{mL}$ penicillin, and $100 \mathrm{mg} / \mathrm{mL}$ streptomycin. Cells were plated in 35-mm Petri dishes at a density of about $2.5 \times 10^{5}$ cells per dish and were grown in a humidified atmosphere of $95 \%$ air- $5 \% \mathrm{CO}_{2}$ at $37 \mathrm{C}$. The culture medium was changed $24 \mathrm{~h}$ after seeding, and cells were used after 5 days of culture. For studies using suspended cells, cells were incubated in culture medium for a resting period of $12 \mathrm{~h}$. After centrifugation (10 min; $100 \times g$ ), cells were suspended in Hank's buffered saline (HBS)-glucose (HBS: NaCl, $130 \mathrm{mmol} / \mathrm{L} ; \mathrm{KCl}, 3.5 \mathrm{mmol} / \mathrm{L} ; \mathrm{CaCl}_{2}, 1.8 \mathrm{mmol} / \mathrm{L} ; \mathrm{MgCl}_{2}$, $0.5 \mathrm{mmol} / \mathrm{L} ; \mathrm{NaHCO}_{3}, 2.5 \mathrm{mmol} / \mathrm{L}$; HEPES, $5 \mathrm{mmol} / \mathrm{L}$ ) at a density of $5 \times 10^{5}$ cells/tube.

\section{Cyclic AMP determination}

Cyclic AMP production was determined by measuring the conversion of $\left[{ }^{3} \mathrm{H}\right] \mathrm{ATP}$ into $\left[{ }^{3} \mathrm{H}\right] \mathrm{cAMP}$, as previously described (36). Briefly, cultured cells were incubated at $37 \mathrm{C}$ for $1 \mathrm{~h}$ in Opti-MEM culture 
medium containing $2 \mu \mathrm{Ci} / \mathrm{mL}\left[{ }^{3} \mathrm{H}\right]$ adenine. The cultures were washed with HBS buffer and incubated in the same buffer, containing $1 \mathrm{mmol} / \mathrm{L}$ isobutyl methylxanthine, for $15 \mathrm{~min}$ at $37 \mathrm{C}$. Cultured cells were incubated with PACAP38 for an additional $15 \mathrm{~min}$ at $37 \mathrm{C}$. The reaction was stopped by aspiration of the medium and addition of $1 \mathrm{~mL} \mathrm{5 \%}$ trichloroacetic acid. Cells were scraped with a rubber policeman, and $100 \mu \mathrm{L}$ of cold solution of ATP and CAMP ( $5 \mathrm{mmol} / \mathrm{L}$ each) was added to the mixture. Cell membranes were pelleted at 5,000 $\times g$ for $15 \mathrm{~min}$, and the supernatants were sequentially chromatographed on Dowex and alumina columns, as previously described (37), allowing the separation of $\left[{ }^{3} \mathrm{H}\right]$ ATP nucleotide from $\left[{ }^{3} \mathrm{H}\right]$ cAMP. cAMP formation was expressed as: $\%$ conversion $=\left(\left[{ }^{3} \mathrm{H}\right] \mathrm{cAMP} /\left(\left[{ }^{3} \mathrm{H}\right] \mathrm{cAMP}+\left[{ }^{3} \mathrm{H}\right] \mathrm{ATP}\right) \times 100\right.$ per $15 \mathrm{~min}$.

\section{Measurement of inositol phosphate (InsP) formation}

The effect of PACAP on polyphosphoinositide metabolism was investigated as described previously (38). Briefly, cells were grown for 2 days in Opti-MEM culture medium containing $2 \mu \mathrm{Ci} / \mathrm{mL}$ myo$\left[{ }^{3} \mathrm{H}\right]$ inositol. The radioactive medium was then discarded, and the cells were incubated in isotope-free and serum-free culture medium. After $30 \mathrm{~min}$, cells were washed, incubated for $15 \mathrm{~min}$ in HBS-glucose $/ \mathrm{LiCl}(10 \mathrm{mmol} / \mathrm{L})$ medium, and incubated for another $15 \mathrm{~min}$ at $37 \mathrm{C}$ with PACAP38 in the same medium. The incubation was stopped by aspiration of the medium and addition of $1 \mathrm{~mL}$ of $5 \%$ (vol/vol) perchloric acid and $200 \mu \mathrm{L}$ BSA $(20 \mathrm{mg} / \mathrm{mL})$. Total InsPs were separated by ion exchange chromatography on $(1 \times 8 \mathrm{~cm})$ Dowex columns. The radioactivity found in the InsP fractions was determined by scintillation counting in gel phase in a Beckman $\beta$ counter.

\section{Data analysis}

The data are presented as means \pm SE. Statistical analysis was performed using the one-way ANOVA test. Homogeneity of variance was assessed by Bartlett's test, and $P$ values were obtained from Dunnett's tables.

\section{Results \\ Localization of PACAP-binding sites}

The autoradiographic localization of $\left[{ }^{125} \mathrm{I}\right] \mathrm{PACAP} 27-$ binding sites was performed in the adrenal of fetuses at 14-20 weeks of gestation. The distribution of the binding sites in a 16-week-old fetus is illustrated in Fig. 1A. Labeling of consecutive sections with antibodies against human CgA demonstrated that the autoradiographic labeling was restricted to the chromaffin tissue (Fig. 1, A and B). Histochemical staining of tissue sections with hematoxylin-eosin showed that chromaffin cells formed radial clusters, penetrating the eosinophilic cells of the fetal zone (Fig. 1C). At all developmental stages studied, PACAP-binding sites were found only in the fetal medullary zone.

\section{Characterization of PACAP-binding sites}

Figure 2 illustrates the displacement of [ $\left.{ }^{125} \mathrm{I}\right] \mathrm{PACAP} 27$ binding (Fig. 2A) by increasing concentrations of synthetic PACAP27 (Fig. 2, B-D), PACAP38 (Fig. 2, E-G), or VIP (Fig. $2, \mathrm{H}-\mathrm{J}$ ) on consecutive sections of a fetal adrenal gland at 15 weeks of gestation. Incubation of tissue slices with $10^{-8}$ mol/L PACAP27 (Fig. 2C) or PACAP38 (Fig. 2F) completely abolished the autoradiographic labeling. In contrast, at the same dose, VIP induced only a slight displacement of $\left[{ }^{125} \mathrm{I}\right]$ PACAP27 binding (Fig. 2I).

Similar experiments were performed on adrenal slices from 14- to 20-week-old fetuses, and the autoradiographic labeling was quantified using a computer-assisted image

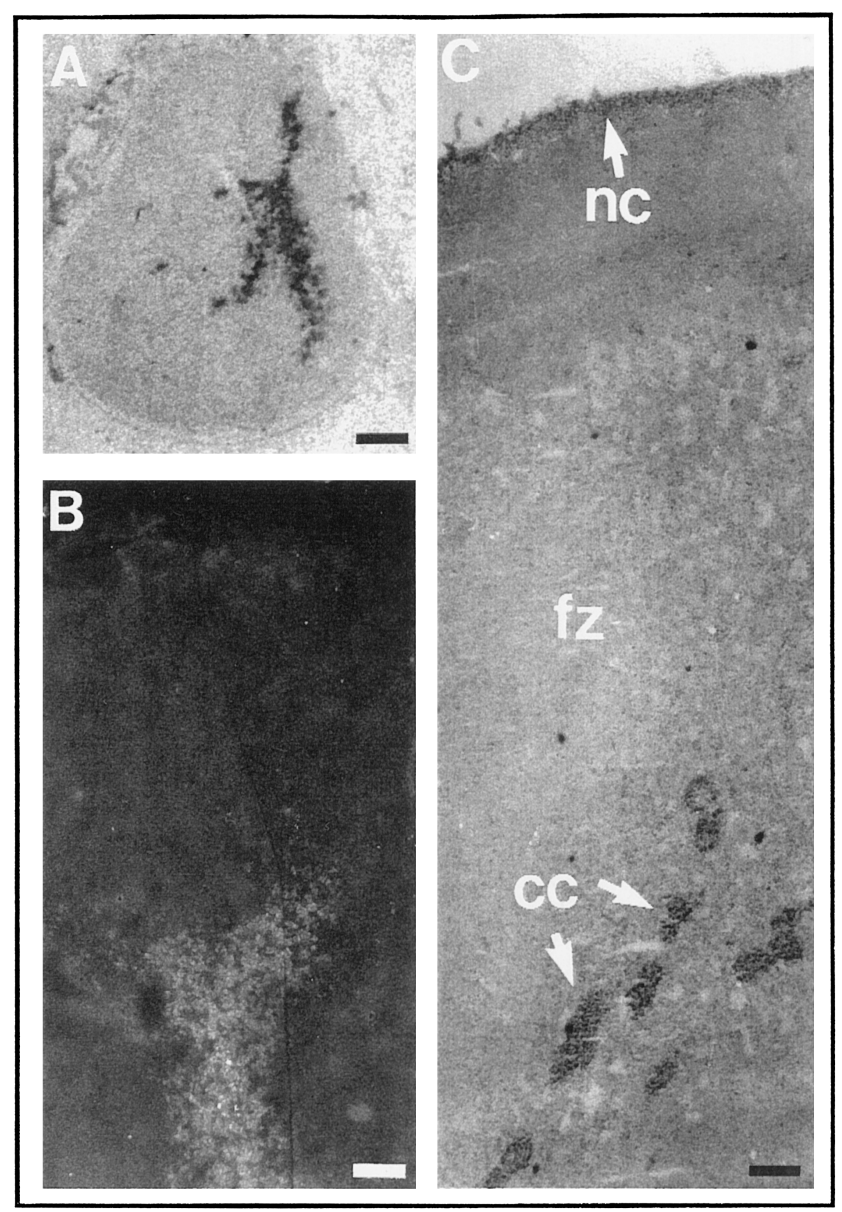

FIG. 1. Microphotographs of sections of an adrenal gland from a 16week-old human fetus. A, Autoradiographic localization of ${ }^{[125}$ I]PACAP27-binding sites; B, immunohistofluorescent localization of chromogranin A-containing cells; C, hematoxylin-eosin staining; CC, chromaffin cells; FZ, fetal zone; NC, neocortex. Bars: $1.4 \mathrm{~mm}(\mathrm{~A})$; $0.6 \mathrm{~mm}(\mathrm{~B}) ; 0.2 \mathrm{~mm}(\mathrm{C})$.

analyzer. At all stages studied, PACAP27 and PACAP38 were more potent than VIP in displacing $\left[{ }^{125} \mathrm{I}\right] \mathrm{PACAP} 27$ binding (Fig. 3, A-F). Scatchard plot analysis of PACAP27 inhibition curves (Fig. 3B inset) revealed that the affinity of PACAP-binding sites and the density of sites were relatively constant throughout the gestation period studied (Table 1). PACAP27 and PACAP38 were equally potent in displacing $\left[{ }^{125} \mathrm{I}\right] \mathrm{PACAP} 27$, whereas VIP was 20 to 500 times less potent than PACAP27 in competing with the tracer during the whole period studied (Table 2). The values of the Hill coefficient were close to 1 for PACAP27 and slightly lower for PACAP38, but systematically inferior to 0.6 for VIP (Table 2).

\section{Effect of PACAP on second-messenger coupling}

The capacity of PACAP38 to stimulate cAMP production was measured both in cell suspensions (used after a 12-h resting period) and in cells cultured for 5 days. In suspended cells, PACAP38 induced a dose-dependent increase in the conversion of ATP into cAMP (Fig. 4A). The $\mathrm{ED}_{50}$ value was $0.07 \pm 0.02 \mathrm{nmol} / \mathrm{L}$, and the maximum 
Fig. 2. Typical autoradiograms show-

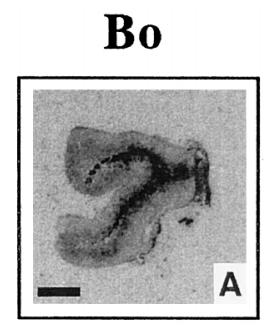
$10^{-9} \mathrm{M} \quad 10^{-8} \mathrm{M} \quad 10^{-6} \mathrm{M}$ ing the displacement of $\left[{ }^{125} \mathrm{I}\right] \mathrm{PACAP} 27$ binding (A) by graded doses of unlabeled PACAP27 (B-D), PACAP38 (E$\mathrm{G})$, or VIP (H-J). All autoradiograms were obtained from $10-\mu \mathrm{m}$ consecutive sections of an adrenal gland from a 15week-old human fetus. Bar: $2 \mathrm{~mm}$ (A-J).
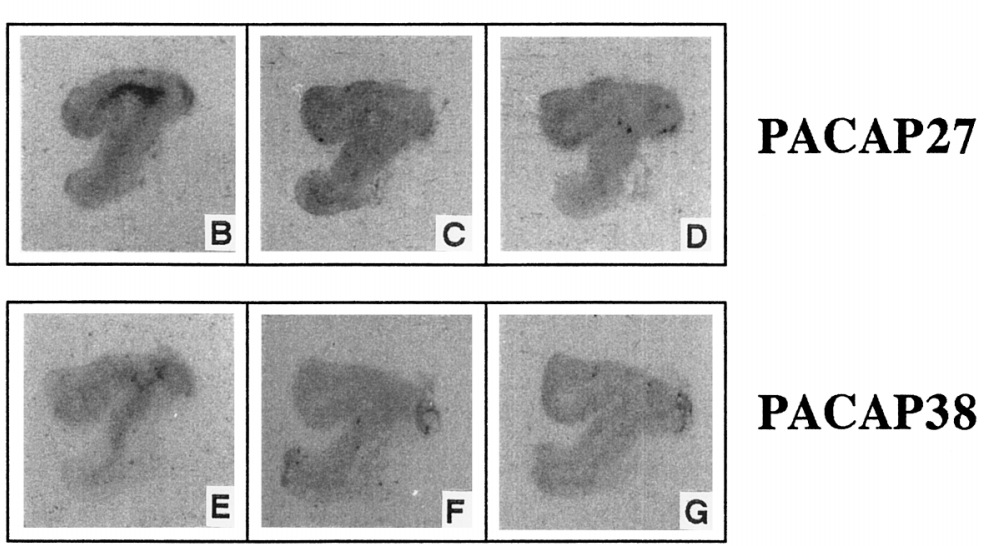

PACAP38

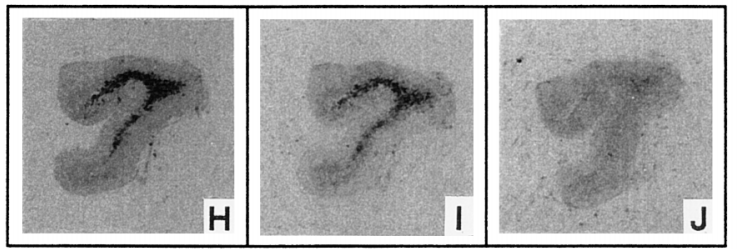

VIP

effect was reached at a dose of $10 \mathrm{nmol} / \mathrm{L}$, with a stimulation ratio of $2.55 \pm 0.25(\mathrm{n}=7, P<0.01)$ over basal value. In cultured cells, the basal conversion of ATP into cAMP was significantly lower than in suspended cells. The $\mathrm{ED}_{50}$ value was $5.4 \pm 1.8 \mathrm{nmol} / \mathrm{L}$, and the maximal effect was reached at a dose of $100 \mathrm{nmol} / \mathrm{L}$, with a stimulation ratio of $3.4 \pm 0.40(\mathrm{n}=9, P<0.001)$ over basal value. In contrast, PACAP38 did not affect InsP accumulation in suspended adrenal cells from 20-week-old fetuses but only induced a modest increase of InsP content (1.30-fold over control) in cells from 15- to 16-week-old fetuses (data not shown).

\section{Discussion}

The presence of PACAP in the adrenal gland and the effect of the neuropeptide on catecholamine and steroid secretion have been documented in various mammalian species. In contrast, little is known concerning the possible role of PACAP in the human adrenal gland. The present study provides the first evidence for the occurrence of functional PACAP receptors in fetal chromaffin cells.

\section{Localization and characterization of PACAP-binding sites}

Autoradiographic labeling, using $\left[{ }^{125}\right.$ I]PACAP27 as a radioligand, revealed the presence of a high density of binding sites in the central zone of the gland. Immunohistochemical staining of adrenal slices with antibodies against human $\mathrm{CgA}$, a selective marker of neuroendocrine cells (29), demonstrated that PACAP-binding sites are exclusively borne by chromaffin cells. The strong autoradiographic signal observed at the earlier stage studied (14-week-old fetuses) is consistent with previous reports indicating that, in the developing human adrenal gland, chromaffin cells establish their phenotype as early as 6 weeks of gestation, as evidenced by the expression of $\mathrm{CgA}$ and tyrosine hydroxylase $(29,39)$. The fetal human adrenal cortex is composed of a thin outer zone (neocortex) and a large fetal zone that represents over $80 \%$ of the gland (26, 27). The present study showed that both of these cortical zones are virtually devoid of PACAP-binding sites. In agreement with this observation, autoradiographic labeling, membrane binding assay, and in situ hybridization immunohistochemistry studies indicate that, in the adult rat adrenal gland, PACAP-binding sites are located only on chromaffin cells (20-22).

Scatchard plot analysis of PACAP-binding in the fetal human chromaffin tissue showed the existence of highaffinity binding sites with $\mathrm{K}_{\mathrm{d}}$ values ranging from 0.32 $0.74 \mathrm{nmol} / \mathrm{L}$. Displacement experiments demonstrated that PACAP27 and PACAP38 were equally potent in competing with the radioligand at all developmental stages studied, whereas VIP was a much weaker competitor. These data revealed that the binding sites evidenced with ${ }^{[25}$ I]PACAP27 correspond predominantly to type I PACAP receptors. The fact that the Hill coefficients measured with PACAP27 were close to 1 suggested that the peptide interacts with a single class of receptors. However, the lower Hill coefficient value calculated with VIP as a competitor would indicate the existence of a heterogeneous population of PACAP/VIP receptors, as previously reported in rat $(20,40,41)$ and human adult adrenal medulla (42).

\section{Second-messenger coupling of PACAP receptors}

There is now clear evidence that type I PACAP receptors can be coupled to adenylyl cyclase and phospholipase C $(6-7,10)$. We have thus investigated the transduction mechanisms associated with the PACAP binding sites in fetal human adrenomedullary cells. We found that PACAP38 stimulated, in a dose-dependent manner, cAMP production from both isolated and cultured adrenal cells. The concen- 
A

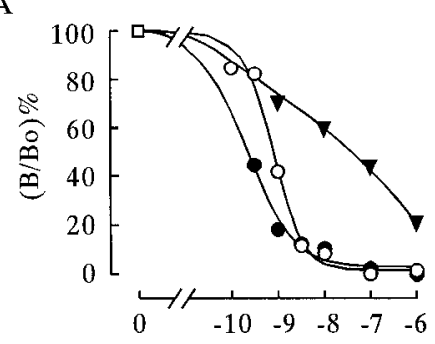

$\mathrm{C}$

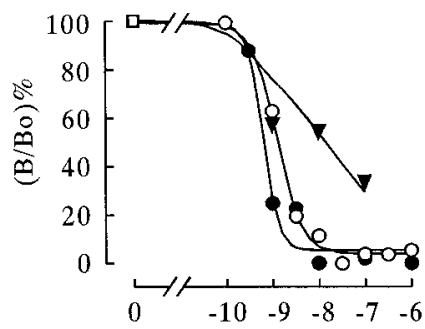

$\mathrm{E}$

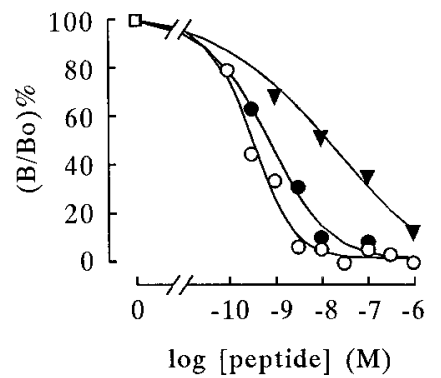

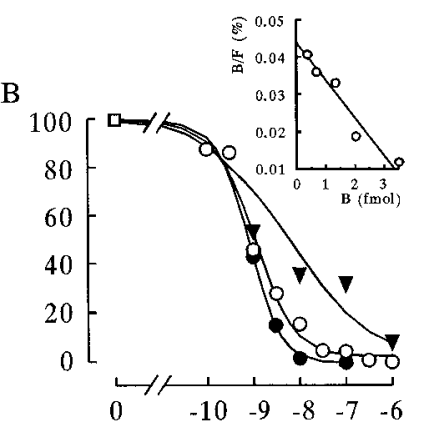

$\mathrm{D}$

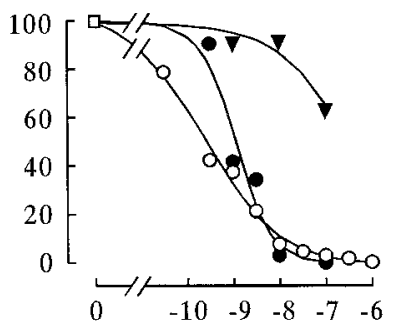

F

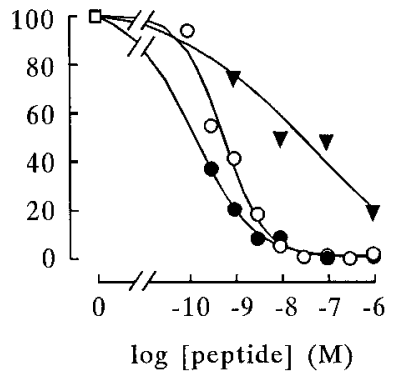

FIG. 3. Representative competition curves showing the displacement of $\left[{ }^{125} \mathrm{I}\right]$ PACAP27 binding on adrenal slices from human fetuses by graded concentrations of unlabeled PACAP27 (○-○), PACAP38 $(\bullet-\bullet)$, or VIP $(\boldsymbol{\nabla}-\boldsymbol{\nabla})$. The curves were obtained by quantification of autoradiograms similar to those shown in Fig. 2. The six graphs correspond to six different ages of gestation: A, 14 weeks; B, 15 weeks; C, 16 weeks; D, 18 weeks; E, 19 weeks; and F, 20 weeks. Inset, Scatchard representation of the displacement curve by PACAP27, shown in B.

tration of ligand which causes 50\% inhibition of the binding $\left(\mathrm{IC}_{50}\right)$ for PACAP27 binding and the $\mathrm{ED}_{50}$ for cAMP formation were in the same range $(0.3$ and $0.07 \mathrm{nmol} / \mathrm{L}$, respectively), showing the existence of a good correlation between binding and coupling potency. These data indicate that the binding sites visualized by autoradiography actually correspond to functional receptors positively coupled to adenylyl cyclase. However, although PACAP38 stimulates both adenylyl cyclase and phospholipase C activity in porcine adrenochromaffin cells (43), we found that PACAP causes only a slight increase in InsP formation. The modest effect of PACAP on phospholipase $C$ activity suggests that fetal human adrenal cells express either the SV1 or the SV3 splice variants of the PACAP receptor, which exhibit a low efficacy for phospholipase $C$ activation (44). Alternatively, the Gq protein, which is required for receptor coupling to phospholipase $C$, may be expressed at a very low level at this stage of fetal develop-

TABLE 1. Affinity and binding capacity of $\left[{ }^{125} \mathrm{I}\right] \mathrm{PACAP} 27$ binding sites in the fetal human adrenal

\begin{tabular}{ccc}
\hline $\begin{array}{c}\text { Weeks of } \\
\text { gestation }\end{array}$ & $\mathrm{K}_{\mathrm{d}}(\mathrm{nmol} / \mathrm{L})$ & $\begin{array}{c}\text { Bmax } \\
(\mathrm{pmol} / \mathrm{mg} \text { wet tissue })\end{array}$ \\
\hline 14 & $0.39 \pm 0.10$ & $0.43 \pm 0.14$ \\
15 & $0.37 \pm 0.07$ & $0.30 \pm 0.06$ \\
16 & $0.54 \pm 0.01$ & $0.35 \pm 0.02$ \\
17 & $0.74 \pm 0.04$ & $0.46 \pm 0.05$ \\
18 & $0.54 \pm 0.06$ & $0.81 \pm 0.10$ \\
19 & $0.32 \pm 0.03$ & $0.35 \pm 0.07$ \\
20 & $0.59 \pm 0.04$ & $0.69 \pm 0.09$ \\
\hline
\end{tabular}

Sections of fetal adrenal glands were processed for autoradiography as described in Materials and Methods. $\mathrm{K}_{\mathrm{d}}$ and Bmax values were determined from Scatchard plot analysis of competition studies using PACAP27 as a competitor. Results are the mean \pm SE. Bmax, binding capacity.

ment in human adrenochromaffin cells. In support of this latter hypothesis, we found that fluoroaluminate, a nonspecific activator of all heterotrimeric $G$ proteins, induces a 2-fold increase in InsP production in fetal adrenal cells, compared with a 15-fold increase in adult cells (data not shown).

\section{Functional implications}

The role of PACAP in the human adrenal during development is currently unknown. In vivo and in vitro studies on animal models have shown that PACAP stimulates tyrosine hydroxylase activity and catecholamine secretion from chromaffin cells $(21,43,45)$. It has recently been reported that PACAP also enhances catecholamine release from adult human adrenal explants (46). These data suggest that PACAP may also exert a stimulatory effect on catecholamine secretion by fetal adrenochromaffin cells. In support of this hypothesis, immunohistochemical studies have shown the presence of both tyrosine hydroxylase and dopamine $\beta$-hydroxylase in human chromaffin cells at early stages of development $(28,39)$.

In the adult human adrenal gland, Neri et al. (46) have shown that PACAP stimulates aldosterone and 18-OH-corticosterone secretion, probably via an indirect mechanism involving the release of catecholamines by chromaffin cells. This paracrine effect of PACAP in the adult adrenal tissue is facilitated by the existence of islets and medullary rays within the adrenal cortex $(47,48)$. In the fetal human adrenal, a paracrine mode of action is even more plausible, inasmuch as, during ontogenesis, chromaffin cells migrate centripetally through the cortex towards their central destination $(29,39)$.

PACAP is known to act as a growth factor, modulating proliferation, survival, and differentiation of various types of neuronal cells $(18,49,50)$. In particular, PACAP has been shown to induce neurite outgrowth and tyrosine hydroxylase gene expression in cultured rat chromaffin cells $(24,25)$ and PC12 cells (51). It is thus conceivable that PACAP also may affect the migration and/or differentiation of immature human chromaffin cells.

In conclusion, the present study has shown that type I PACAP receptors are expressed in human chromaffin cells in 14- to 20-week-old fetuses and that these receptors are functionally coupled to adenylyl cyclase. These data suggest that PACAP may play a role in the differentiation and/or secre- 
TABLE 2. Half-maximum displacement and Hill coefficients of $\left[{ }^{125} \mathrm{I}\right] \mathrm{PACAP} 27$ binding sites in the fetal human adrenal gland

\begin{tabular}{|c|c|c|c|c|c|c|}
\hline \multirow{2}{*}{ Weeks of gestation } & \multicolumn{3}{|c|}{$\mathrm{IC}_{50}(\mathrm{nmol} / \mathrm{L})$} & \multicolumn{3}{|c|}{ Hill coefficients } \\
\hline & PACAP27 & PACAP38 & VIP & PACAP27 & PACAP38 & VIP \\
\hline 14 & $0.35 \pm 0.15$ & 0.22 & 311 & $0.99 \pm 0.04$ & 0.82 & 0.23 \\
\hline 15 & $0.28 \pm 0.04$ & 0.23 & 4 & $0.93 \pm 0.10$ & 0.80 & 0.26 \\
\hline 16 & $0.46 \pm 0.02$ & 0.52 & 141 & $1.04 \pm 0.11$ & 0.90 & 0.19 \\
\hline 18 & $0.64 \pm 0.08$ & 0.15 & 362 & $0.92 \pm 0.05$ & 0.74 & 0.58 \\
\hline 19 & $0.29 \pm 0.03$ & 0.81 & 11 & $0.91 \pm 0.02$ & 0.69 & 0.28 \\
\hline 20 & $0.51 \pm 0.04$ & 0.29 & 41 & $0.93 \pm 0.03$ & 0.82 & 0.27 \\
\hline
\end{tabular}

Sections of fetal adrenal glands were processed for autoradiography as described in the Materials and Methods section. $\mathrm{IC}_{50}$ and Hill coefficients obtained with PACAP27 are the mean \pm SE of at least three independent experiments. For PACAP38 and VIP, results are the mean of two independent experiments.

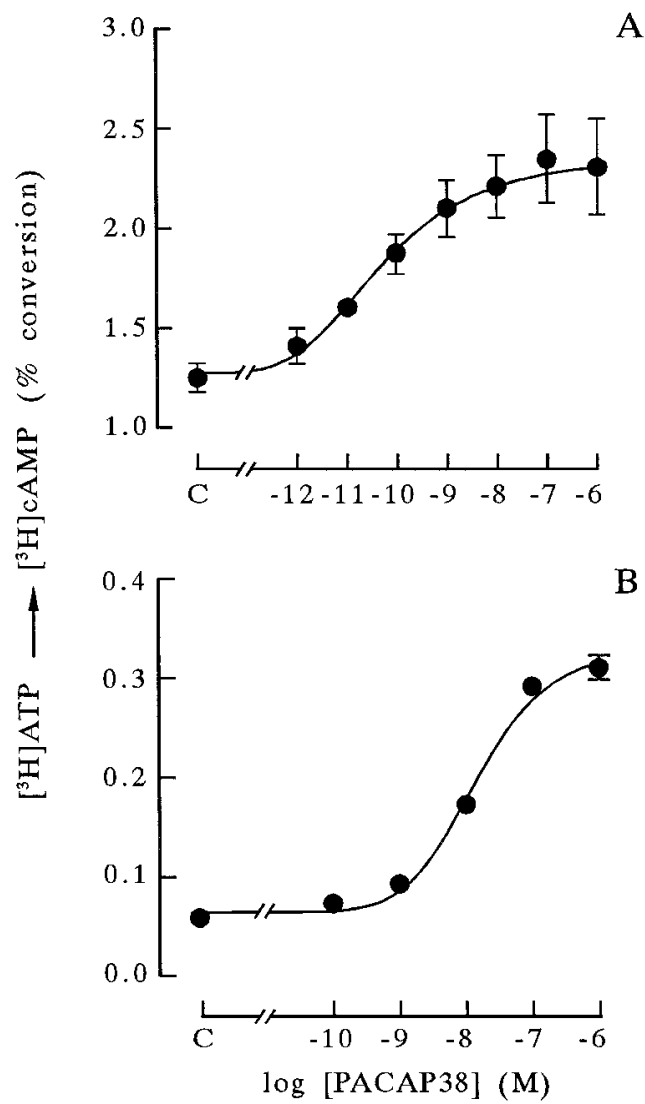

Fig. 4. Effect of PACAP38 on cAMP production by adrenal cells from 18- to 20 -week-old human fetuses. Suspended cells, used after a 12-h resting period (A) or cells cultured for 5 days (B), were labeled with $\left[{ }^{3} \mathrm{H}\right]$ adenine and then incubated for $15 \mathrm{~min}$ at $37 \mathrm{C}$ in the absence (control) or in the presence of graded concentrations of PACAP38. Conversion of ATP into cAMP was calculated as described in Materials and Methods. Results are the mean $( \pm \mathrm{SE})$ of triplicate determinations from one representative experiment out of three. When no error bars are shown, they are contained within the symbols.

tory activity of chromaffin cells in the fetal human adrenal gland.

\section{Acknowledgments}

The authors would like to thank Ms. Huguette Lemonnier (INSERM U413) and Lucie Chouinard (Service of Endocrinology, Sherbrooke) for skillful technical assistance. We appreciate the advice from Drs. Magali Basille and Bruno Gonzalez (INSERM U413) for autoradiography.

\section{References}

1. Miyata A, Arimura A, Dahl R, et al. 1989 Isolation of a novel 38-residues hypothalamic polypeptide which stimulates adenylate cyclase in pituitary cells. Biochem Biophys Res Commun. 164:567-574.

2. Miyata A, Jiang L, Dahl R, et al. 1990 Isolation of a neuropeptide corresponding to the N-terminal 27 residues of the pituitary adenylate cyclase-activating polypeptide with 38-residues (PACAP 38). Biochem Biophys Res Commun. 170:643-648.

3. Arimura A. 1992 Pituitary adenylate cyclase-activating polypeptide (PACAP): discovery and current status of research. Regul Pept. 37:287-303.

4. Chartrel N, Tonon MC, Vaudry H, Conlon JM. 1991 Primary structure of frog pituitary adenylate cyclase-activating polypeptide (PACAP) and effects of ovine PACAP on frog pituitary. Endocrinology. 129:3367-3371.

5. Rawlings SR, Hezareh M. 1996 Pituitary adenylate cyclase-activating polypeptide (PACAP) and PACAP/vasoactive intestinal polypeptide receptors: action on the anterior pituitary gland. Endocr Rev. 17:4-29.

6. Christophe J. 1993 Type I receptors for PACAP (a neuropeptide even more important than VIP?). Biochim Biophys Acta. 1154:183-199.

7. Arimura A, Shioda S. 1995 Pituitary adenylate cyclase-activating polypeptide (PACAP) and its receptors: neuroendocrine and endocrine interaction. Front Neuroendocrinol. 16:53-88.

8. Ishihara T, Shigemoto R, Mori K, Takahashi K, Nagata S. 1992 Functional expression and tissue distribution of a novel receptor for vasoactive intestinal polypeptide. Neuron. 8:811-819.

9. Lutz EM, Sheward WJ, West KM, Morrow JA, Fink G, Harmar AJ. 1993 The VIP-2 receptor: molecular characterization of a cDNA encoding a novel receptor for vasoactive intestinal polypeptide. FEBS Lett. 33:3-8.

10. Spengler D, Waeber C, Pantaloni C, et al. 1993 Differential signal transduction by five splice variants of the PACAP receptor. Nature. 365:170-175.

11. Ghatei MA, Takahashi K, Suzuki Y, Gardiner J, Jones PM, Bloom SR. 1993 Distribution, molecular characterization of pituitary adenylate cyclase-activating polypeptide and its precursor encoding messenger RNA in human and rat tissues. J Endocrinol. 36:159-166.

12. Yon L, Feuilloley M, Chartrel N, Arimura A, Fournier A, Vaudry H. 1993 Localization, characterization and activity of pituitary adenylate cyclase-activating polypeptide in the frog adrenal gland. J Endocrinol. 139:183-194.

13. Tabarin A, Chen D, Håkanson R, Sundler F. 1994 Pituitary adenylate cyclaseactivating peptide in the adrenal gland of mammals: distribution, characterization and responses to drugs. Neuroendocrinology. 59:113-119.

14. Masuo Y, Tokito F, Matsumoto Y, Shimamoto N, Fujino M. 1994 Ontogeny of pituitary adenylate cyclase-activating polypeptide (PACAP) and its binding sites in the rat brain. Neurosci Lett. 170:43-46.

15. Tatsuno I, Somogyvari-Vigh A, Arimura A. 1994 Developmental changes of pituitary adenylate cyclase-activating polypeptide (PACAP) ands its receptors in the rat brain. Peptides. 15:55-60.

16. Basille M, Gonzalez BJ, Leroux P, Jeandel L, Fournier A, Vaudry H. 1993 Localization and characterization of PACAP receptors in the rat cerebellum during development: evidence for a stimulatory effect of PACAP on immature cerebellar granule cells. Neuroscience. 57:329-338.

17. Basille M, Gonzalez BJ, Fournier A, Vaudry H. 1994 Ontogeny of pituitary adenylate cyclase-activating polypeptide (PACAP) receptors in the rat cerebellum: a quantitative autoradiographic study. Dev Brain Res. 82:81-89.

18. Gonzalez BJ, Basille M, Vaudry D, Fournier A, Vaudry H. 1997 Pituitary adenylate cyclase-activating polypeptide (PACAP) promotes cell survival and neurite outgrowth in rat cerebellar neuroblasts. Neuroscience. 78:419-430.

19. Matsumoto H, Koyama C, Sawada T, et al. 1993 Pituitary folliculostellate-like cell line (TtT/GF) responds to novel hypophysiotropic peptide (pituitary adenylate cyclase-activating polypeptide), showing increased adenosine $3^{\prime}, 5^{\prime}$ monophosphate and interleukin-6 secretion and cell proliferation. Endocrinology. 133:2150-2155.

20. Shivers B, Görcs T, Gottschall P. 1991 Two high-affinity binding sites for pituitary adenylate cyclase-activating polypeptide (PACAP) have different tissue distribution. Endocrinology. 128:3055-3065.

21. Watanabe T, Masuo Y, Matsumoto H, et al. 1992 Pituitary adenylate cyclase- 
activating polypeptide provokes cultured rat chromaffin cells to secrete adrenaline. Biochem Biophys Res Commun. 182:403-411.

22. Moller K, Sundler F. 1996 Expression of pituitary adenylate cyclase-activating polypeptide (PACAP) and PACAP type I receptors in the rat adrenal medulla. Regul Pept. 63:129-139.

23. Frödin M, Hannibal J, Wulff BS, Gammeltoft S, Fahrenkrug J. 1995 Neuronal localization of pituitary adenylate cyclase-activating polypeptide-38 in the adrenal medulla and growth inhibitory effect on chromaffin cells. Neuroscience. 65:599-608.

24. Tischler AS, Riseberg JC, Gray R. 1995 Mitogenic and antimitogenic effects of pituitary adenylate cyclase-activating polypeptide (PACAP) in adult rat chromaffin cell cultures. Neurosci Lett. 189:135-138.

25. Wolf N, Krieglstein K. 1995 Phenotypic development of neonatal rat chromaffin cells in response to adrenal growth factors and glucocorticoids: focus on pituitary adenylate cyclase-activating polypeptide. Neurosci Lett. 200:207-210.

26. Winter JSD. 1992 Fetal and neonatal adrenocortical development. In: James VHT, ed. The adrenal gland. 2nd ed. New York: Raven Press; 159-189.

27. Bocian-Sobkowska J, Malendowicz LK, Wozniak T. 1993 Cytological aspects of the human adrenal cortex development in the course of intra-uterine life. Histol Histopathol. 8:725-730.

28. Cooper MJ, Hutchins GM, Israel MA. 1990 Histogenesis of the human adrenal medulla. Am J Pathol. 137:605-615.

29. Ehrhart-Bornstein M, Breidert M, Guadanucci P, et al. $199717 \alpha$-hydroxylase and chromogranin A in 6th week human fetal adrenals. Horm Metab Res. 29:30-32.

30. Chartrel N, Conlon JM, Danger JM, Fournier A, Tonon MC, Vaudry H. 1991 Characterization of melanotropin release-inhibiting factor (melanostatin) from frog brain: homology with human neuropeptide Y. Proc Natl Acad Sci USA. 6:249-255.

31. Laquerrière A, Leroux P, Gonzalez B, Bodenant C, Benoit R, Vaudry H. 1989 Distribution of somatostatin receptors in the brain of the frog Rana ridibunda: correlation with the localization of somatostatin-containing neurons. J Comp Neurol. 280:451-467.

32. Yon L, Chartrel N, Feuilloley M, et al. 1994 Pituitary adenylate cyclaseactivating polypeptide stimulates both adrenocortical cells and chromaffin cells in the frog adrenal gland. Endocrinology. 135:2749-2758.

33. Streeter GL. 1920 Weight, sitting height, head size, foot length and menstrual age of the human embryo. Contr Embryol. 11:143-179.

34. Leroux P, Gonzalez BJ, Bucharles C, Vaudry H. 1991 Autoradiographic study of somatostatin receptors in the rat cerebellum. Methods Neurosci. 5:538-553.

35. Breault L, Lehoux JG, Gallo-Payet N. 1996 The angiotensin AT2 receptor is present in the fetal human adrenal gland throughout the second trimester of gestation. J Clin Endocrinol Metab. 81:3914-3922.

36. Gallo-Payet N, Payet MD. 1989 Excitation-secretion coupling: involvement of potassium channels in ACTH-stimulated rat adrenocortical cells. J Endocrinol. 120:409-421.

37. Salomon Y, Londos C, Rodbell M. 1974 A highly sensitive adenylate cyclase assay. Anal Biochem. 58:541-548.

38. Gallo-Payet N, Guillon G, Balestre MN, Jard S. 1986 Vasopressin induces breakdown of membrane phosphoinositides in adrenal glomerulosa and fasciculata cells. Endocrinology. 19:1042-1047.

39. Molenaar WM, Lee VMY Trojanowski JQ. 1990 Early fetal acquisition of the chromaffin and neuronal immunophenotype by human adrenal medullary cells. An immunohistological study using monoclonal antibodies to chromogranin A, synaptophysin, tyrosine hydroxylase, and neuronal cytoskeletal proteins. Exp Neurol. 108:1-9.

40. Mazzochi G, Malendowicz LK, Meneghelli V, Gottardo G, Nussdorfer GG. 1993 Vasoactive intestinal polypeptide (VIP) stimulates hormonal secretion of the rat adrenal cortex in vitro: evidence that adrenal chromaffin cells are involved in the mediation of the mineralocorticoid, but not glucocorticoid secretagogue action of VIP. Biomed Res. 14:435-440.

41. Hinson JP, Ho MM, Vinson GP, Kapas S. 1996 Vasoactive intestinal peptide is a local regulator of adrenocortical function. Endocr Res. 22:831-838.

42. Bornstein SR, Haidan A, Ehrhart-Bornstein M. 1996 Cellular communication in the neuro-adrenocortical axis: role of vasoactive intestinal polypeptide (VIP). Endocr Res. 22:819-829.

43. Isobe K, Nakai T, Takuwa Y. $1993 \mathrm{Ca}^{2+}$-dependent stimulatory effect of pituitary adenylate cyclase-activating polypeptide on catecholamine secretion from cultured porcine adrenal medullary chromaffin cells. Endocrinology. 132:1757-1765.

44. Pisegna JR, Wank SA. 1996 Cloning and characterization of the signal transduction of four splice variants of the human pituitary adenylate cyclaseactivating polypeptide receptor. J Biol Chem. 271:17267-17274.

45. Marley PD, Cheung CY, Thomson KA, Murphy R. 1996 Activation of tyrosine hydroxylase by pituitary adenylate cyclase-activating polypeptide (PACAP27) in bovine adrenal chromaffin cells. J Auton Nerv Syst. 60:141-146.

46. Neri G, Andreis P, Prayer-Galetti T, Rossi G, Malendowicz L, Nussdorfer GG. 1996 Pituitary adenylate cyclase-activating polypeptide enhances aldosterone secretion of human adrenal gland: evidence for an indirect mechanism, probably involving the local release of catecholamines. J Clin Endocrinol Metab. 81:169-173.

47. Gallo-Payet N, Pothier P, Isler H. 1987 On the presence of chromaffin cells in the adrenal cortex: their possible role in adrenocortical function. Biochem Cell Biol. 65:588-592.

48. Bornstein SR, Gonzalez-Hernandez JA, Ehrhart-Bornstein M, Adler G, Scherbaum WA. 1994 Intimate contact of chromaffin and cortical cells within the human adrenal gland forms the cellular basis for important intraadrenal interactions. J Clin Endocrinol Metab. 78:225-232.

49. Deutsch PJ, Shadlow VC, Barzilai N. 1993 38-amino acid form of pituitary adenylate cyclase-activating polypeptide induces process outgrowth in human neuroblastoma cells. J Neurosci Res. 35:312-320.

50. Vaudry D, Gonzalez BJ, Basille M, Anouar Y, Fournier A, Vaudry H. 1998 PACAP stimulates both c-fos gene expression and cell survival in rat cerebellar granule neurons through activation of the protein kinase A pathway. Neuroscience. 84:801-812.

51. Deutsch PJ, Sun Y. 1992 The 38-amino acid form of pituitary adenylate cyclaseactivating polypeptide stimulates dual signaling cascades in PC12 cells and promotes neurite outgrowth. J Biol Chem. 267:5108-5113.

\section{The American Autonomic Society presents}

The IX International Symposium of the Autonomic Nervous System October 30-November 1, 1998 Ft. Myers, Florida

Deadline for abstracts is July 15, 1998.

For complete information, contact Anita Zeller or Sue Paxton, Registrars, American Autonomic Society, Mayo Clinic, 811 Guggenheim Building, 200 First Street SW, Rochester, Minnesota 55905; Phone: 507-2843375, Fax: 507-284-3133, E-Mail: zeller.anita@mayo.edu. 